KONSTAN
JURNAL FISIKA DAN PENDIDIKAN FISIKA
Volume 5, Nomor 2, Desember 2020
$\begin{array}{r}\text { E-ISSN : 2460-9129 dan P-ISSN : 2460-9110 } \\ \text { http://jurnalkonstan.ac.id/index.php/jurnal }\end{array}$

\title{
PENERAPAN MODEL PEMBELAJARAN KOOPERATIF TIPE INVESTIGASI KELOMPOK UNTUK MENINGKATKAN AKTIVITAS DAN HASIL BELAJAR SISWA FISIKA KELAS X MA RAUDLATUSSHIBYAN NW BELENCONG TAHUN PELAJARAN 2019/2020
}

\author{
Nur Faujiah"), Muh. Wahyudi ${ }^{1 *}$, Bahtiar ${ }^{1)}$ \\ 1) Program Studi Tadris Fisika, Fakultas Tarbiyah dan KeguruanUniversitas Islam \\ Negeri Mataram, Jalan Gajah Mada No.100 Jempong Timur, Kota Mataram, \\ Indonesia
}

\section{Info Artikel}

Sejarah Artikel:

Diterima 02 Juli 2020

Disetujui 19 November 2020

Dipublikasikan 30

Desember 2020

\section{Kata Kunci:}

Model pembelajaran

kooperatif tipe

invstigasi kelompok, aktivitas belajar, hasil belajar.

\begin{abstract}
Abstrak
Penelitian ini bertujuan untuk mengetahui penerapan model pembelajaran kooperatif tipe investigasi kelompok pada salah satu Madrasah Aliyah dalam meningkatkan aktivitas dan hasil belajar peserta didik dalam pelajaran fisika. Jenis penelitian ini menggunakan Penelitian Tindakan Kelas (PTK) yang dilaksanakan dalam dua siklus. Setiap siklus dilakukan empat tahap yaitu: Perencanaan (Planning), tahap pelaksanaan tindakan (action), tahap observasi (observation), dan tahap refleksi (reflection). Subjek penelitian ini adalah siswa kelas X MA Raudlatusshibyan NW Belencong yang berjumlah 32 orang siswa. Data diperoleh dari hasil tes siswa, nilai laporan dan lembar observasi. Hasil penelitian menunjukkan terjadinya peningkatan. Hal ini dibuktikan dengan hasil pretest dan hasil postest siswa. Untuk nilai aktivitas siswa pada siklus I $60 \%$ pada siklus II mengalami peningkatan yaitu $85 \%$. Untuk hasil belajar siswa pada siklus I sebelum deberi tindakan siswa mendapat nilai pada pretest yaitu $37,5 \%$ setelah diberi tindakan mendapat nilai protest yaitu $71,87 \%$. Pada siklus II nilai pretest siswa memperoleh $68,75 \%$ kemudian pada postest memperoleh nilai $87,5 \%$. Dapat disimpulkan bahwa dengan menggunakan model pembelajaran kooperatif aktivitas dan hasil belajar siswa meningkat dengan sangat baik dan signifikan.
\end{abstract}

(C) 2020 Universitas Islam Negeri Mataram

\footnotetext{
* Corresponding Author:muhwahyudi@uinmataram.ac.id
}

Alamat korespodensi:

Gedung Pasca Sarjana Lantai 3 Kampus 2 UIN Mataram, Jl. Gajah Mada 100 Jempong Mataram, Indonesia Email: jurnalkonstan@uinmataram.ac.id 


\section{PENDAHULUAN}

Fisika merupakan ilmu yang bersifat empiris, artinya setiap hal yang dipelajari dalam fisika didasarkan pada hasil pengamatan terhadap gejala-gejala alam. Dengan demikian dalam suatu pembelajaran siswa diharapkan tidak hanya menghafal, melainkan juga memahami mata pelajaran fisika baik dari teori maupun diterapkan melalui gejala alam. Namun, fisika merupakan pelajaran yang sangat sulit, sehingga membuat siswa tidak memiliki motivasi belajar fisika bahkan siswa malas serta memberikan dampak yang kurang menyenangkan terhadap hasil belajar siswa [1].

Oleh karna itu guru harus mengubah cara pandang siswa terhadap mata pelajaran fisika yang dianggap sulit dengan cara dalam melakukan belajar mengajar guru harus menggunakan model pembelajaran yang dapat menarik minat belajar siswa. Karna setiap pemilihan model pembelajaran akan berpengaruh terhadap hasil belajar siswa. Dalam melakukan pemilihan model pembelajaran kenyataanya saat ini masih jarang dilakukan dan diterapkan oleh guru dalam proses pembelajaran, dan ini akan mempengaruhi siswa dalam belajar dan berpengaruh juga terhadap hasil belajar siswa [2].

Guru cenderung lebih menguasai proses belajar dengan menerapkan metode ceramah. Metode ceramah membuat guru mendominasi kegiatan belajar mengajar di kelas menjadi pasif terhadap siswa, serta siswa lebih banyak belajar dengan menerima mencatat dan menghapal saja, sehingga hal tersebut membuat siswa kurang senang belajar fisika [3]. Oleh sebab itu model pembelajaran yang biasa digunakan harus diubah ke model pembelajaran yang baru agar minat siswa dalam belajar mata pelajaran fisika meningkat begitu juga dengan hasil belajar dan aktivitas belajar siswa.

Berdasarkan hasil observasi dan wawancara penelitia dengan guru mata pelajaran fisika di MA Raudlatusshibyan NW Belencong menyatakan bahwa minat belajar siswa terhadap fisika masih sangat kurang hal ini dibuktikan dengan nilai yang didapat siswa masih sangat jauh dari nilai KKM begitu juga dengan cara mengajar guru masih menggunakan metode ceramah dan model pembelajaran yang konvensional yang dimana model ini hanya belajar secara monoton dan pembelajaran hanya berpusat pada guru.

Salah satu model pembelajaran yang tepat untuk digunakan dalam proses belajar mengajar adalah model pembeljaran kooperatif. Seperti yang dinyatakan oleh [4] menyatakan bahwa Salah satu tipe model pembelajaran kooperatif adalah Group Investigation. Dalam kegiatan belajar mengajar sebaiknya guru tidak hanya menyampaikan konsep dan teori saja tetapi juga menekankan pada bagaimana caranya agar siswa dapat memperoleh konsep dan teori tersebut. Pengunaan model pembelajaran kooperatif tipe Group Investigation dapat memudahkan siswa memperoleh konsep dan teori, karena dengan model pembelajaran ini siswa dilatih 
untuk mengamati, mengelompokkan, menafsirkan, meneliti, dan kemudian mengomunikasikan [4].

Sudah banyak para peneliti yang melakukan penelitian menggunakan model pembelajaran kooperatif dalam meningkatkan aktivitas dan hasil belajar pada mata pelajaran fisika dan hasilnya aktivitas maupun hasil belajar siswa pada mata pelajaran fisika meningkat secara drastis dan minat belajar siswa terhadap fisika meningkat secara signifikan setelah diterapkannya model pembelajran fisika. Pembelajaran kooperatif (cooperative learning) merupakan sistem pengajaran yang memberi kesempatan kepada anak didik untuk bekerja sama dengan sesama siswa dalam tugas-tugas yang terstruktur. Group investigasi adalah strategi belajar kooperatif yang menempatkan siswa ke dalam kelompok-kelompok secara heterogen dilihat dari perbedaan kemampuan, gender, etnis dan agama untuk melakukan investigasi terhadap suatu topik [5].

Dalam penelitian yang dilakukan oleh (Yusniati, H dan Muh. Yusuf: 2016) menyatakan bahwa penerapan model pembelajaran kooperatif tipe group investigation sangat baik untuk diterapkan kepada siswa dikarenakan siswa dapat melakukan kegiatan diskusi. Artinya siswa tidak hanya duduk diam meneriama materi dan konsep dari tapi siswa dilatih untuk menemukan penemuan langkahlangkah konsep. Dengan model pembelajaran ini juga siswa dilatih untuk mengemukakan pendapatnya sendiri [6].

Dalam penelitian lain juga seperti penelitian yang dilakukan oleh Yupin Aliwu menyatakan bahwa perancang pembelajaran secara terstruktur tersebut melalui model pembelajaran GI merupakan strategi yang sangat efektifdiciptakan oleh guru dalam pembelajaran sebagai suatu upaya kreatif dalam menyelesaikan berbagai masalah pembelajaran di kelas. hal ini karena mengajar pada dasarnya merupakan suatu usaha untuk menciptakan kondisi atau sistem lingkungan yang mendukung dan memungkinkan untuk berlangsungnya pembelajaran [7].

Di sisi yang lain juga telah banyak dilakukan penelitian yang memberikan solusi yang beragam untuk proses pembelajaran fisika yang memang kurang diminati oleh sebagian peserta didik. pengintegrasian media software tracker dalam pembelajaran akan mampu meningkatkan pemahaman keterampilan proses sains [8], pengembangan alat peraga fisika sangat layak dan mampu meningkatkan pemahaman bagi peserta didik [9].

Penelitian ini sangat penting dilakukan mengingat rendahnya nilai hasil belajar siswa serta kurangnya minat dan aktivitas siswa dalam mata pelajaran fisika di MA Raudlatusshibyan NW Belencong. Penelitian yang berkaitan tentang model pembelajaran kooperatif tipe investigasi kelompok untuk meningkatkan aktivitas dan hasil belajar khususnya pada mata pelajaran fisika sudah lama tidak diteliti berdasarkan jurnal yang saya baca penelitian terakhir dilakukan pada tahun 2016 pada mata pelajaran fisika lebih khususnya pada materi hukum newton sedangkan 
pada penelitian ini peneliti mencoba pada materi Fluida Statis. Penelitian ini bertujuan untuk mengetahui penerapan model pembelajaran kooperatif tipe investigasi kelompok dapat meningkatkan aktivitas dan hasil belajar siswa fisika kelas X MA Raudlatusshibyan NW Belencong. Hipotesis dalam penelitian ini yaitu penerapan model pembelajaran kooperatif tipe investigasi kelompok dapat meningkatkan aktivitas dan hasil belajar siswa fisika kelas X MA Raudlatusshibyan NW Belencong. Penerapan model pembelajaran kooperatif tipe investigasi kelompok akan berdampak untuk meningkatkan aktivitas dan hasil belajar siswa fisika kelas X MA Raudlatusshibyan NW Belencong.

\section{METODE PENELITIAN}

Penelitian ini mengguanakan Penelitian Tindakan Kelas (PTK). Setting penelitian menjelaskan lokasi dan gambar tentang kelompok peserta didik atau objek yang dikenai tindakan. Tidak ada sampel dan populasi dalam PTK. Penelitian Tindakan kelas ini dilaksanakan terhadap peserta didik kelas X IPA MA Raudlatushibyan NW Belencong yang berjumlah 32 orang. Penelitian ini berkolaborasi dengan salah satu observer yaitu guru fisika yang ada di sekolah tersebut. Penelitian ini dilaksanakan di kelas X IPA MA Raudlatusshibyan NW Belencong yang bertempat di Dusun Belencong Desa Midang Kecamatan Gunungsari Kapubaten Lombok Barat.

Sasaran atau tindakan dalam penelitian ini adalah siswa kelas X IPAMA Raudlatusshibyan NW Belencong semester genap dengan fokus penelitian sabagai upaya untuk meningkatkan aktivitas dan hasil belajar siswa. Untuk analisis data digunakan rumus sebagai berikut:

a. Analisis aktivitas siswa menggunakan persamaan 1 [6]

$$
\text { Nilai }=\frac{\text { Jumlah aspek teramati }}{\text { Jumlah seluruh aspek } \text { yang teramati }} \times 100 \%
$$

b. Hasil Belajar diukur menggunakan persamaan 2, 3 dan 4 [10]

$$
\mathrm{M}=\frac{\sum X}{n}
$$

Keterangan:

$\mathrm{M} \quad=$ Rata-rata (Mean)

$\sum \mathrm{X}=$ Nilai yang diperoleh masing-masing siswa

$\mathrm{n}=$ Banyak data

$$
\mathrm{KI}=\frac{\text { Jumlah skor yang diperoleh }}{\text { skor maksimum }} \times 100 \%
$$


Keterangan:

$\mathrm{KI}=$ Ketuntasan Individual

$$
\mathrm{KK}=\frac{P}{N} \times 100 \%
$$

\author{
Keterangan: \\ KK $=$ Ketuntasan Klasikal (\%) \\ $\mathrm{P}=$ Banyak siswa yang memperoleh nilai $>75$ \\ $\mathrm{N}$ = Jumlah Siswa seluruhnya
}

\title{
HASIL DAN PEMBAHASAN
}

Dari hasil lembar observasi dan soal yang diberikan kepada siswa peneliti memperoleh peningkatan aktivitas dan hasil belajar yang drastis. Dalam penelitian ini peneliti melakukan penelitian II siklus. Sebelum diberikan tindakan berupa penerapan model terlebih dahulu guru mengetes kemampuan awal siswa terhadap materi fluida statis sehingga dilakukannlah pretest. Setelah dilakukan pretes ternyata nilai yang sebesar 37,5\% tergolong kedalam kategori kurang pada Iklus I. Kemudian guru menerapkan model dan hasilnya meningkat dan cukup memuaskan untuk siklus I kemudian siklus II guru melakukan pretest lagi agar guru dapat mengetahui apakah siswa masih mengingat materi sebelumnya. Adapun nilai yang didapat pada pretest siklus II yaitu $68,75 \%$ dan hasilnya cukup memuaskan.

Hasil analisis data pada pelaksanaan siklus I dengan menggunakan model pembelajaran kooperatif tipe investigasi kelompok untuk meningkatkan aktivitas dan hasil belajar siswa diperoleh skor unuk aktivitas belajar siswa sebesar $60 \%$ dan untuk hasil belajar siswa dengan menggunakan tes berupa soal pilihan ganda 10 nomor dan essay 5 nomor diperoleh skor 71,87\%. Hal ini dikarenakan masih terdapat kekrungan dalam proses pembeljaran berdasarkan hasil penelitian yang telah dilakukan.

Pada pelaksanaan siklus II dengan menggunakan model pembeljaran kooperatif tipe investigasi kelompok untuk meningkatkan aktivitas dan hasil belajar siswa diperoleh skor untuk aktivitas belajar siswa sebesar 85\%, untuk hasil belajar siswa dengan menggunakan soal pilihan ganda 15 nomor dan soal essay 5 nomor diperoleh skor $87,5 \%$. Untuk kedua tes tersebut tidak perlu dilanjutkan ke siklus berikutnya karena telah mengalami peningkatan yang signifikan.

Perbandingan hasil tes antara aktivitas dan hasil belajar siswa dalam dua siklus dapat dilihat melalui tabel 1. 
Tabel 1. Perbandingan Aktivitas dan Hasil Belajar Siswa

\begin{tabular}{cccc}
\hline No & Aspek & Siklus I & Siklus II \\
\hline 1 & Aktivitas Belajar Siswa & $60 \%$ & $85 \%$ \\
\hline 2 & Hasil Belajar Siswa & $71,87 \%$ & $87,5 \%$ \\
\hline
\end{tabular}

Berdasarkan hasil analisis dan penelitian, diperoleh bahwa pembelajaran menggunakan model pembelajaran kooperatif tipe investigasi kelompok dapat meningkatkan aktivitas dan hasil belajar siswa. Dengan model pembelajaran kooperatif tipe investigasi kelompok mengutamakan peserta didik dalam belajar dan menyelesaikan masalah yang ada, baik dalam materi maupun dalam mengerjakan tugas-tugas yang diberikan guru berkenaan dengan materi yang diberikan. Selain itu model pembelajaran ini menggunakan masalah dunia nyata sebagai suatu konteks bagi peserta didik untuk belajar tentang cara berpikir kreatif dan keterampilan pemecahan masalah, serta untuk memperoleh pengetahuan yang esensial dari materi yang dipelajari. Pembuatan media pembelajaran juga sangat dibutuhkan untuk memberikan tambahan pengalaman bagi peserta didik dalam mengkonstruksi pemahamannya [11]. Di sisi yang lain identifikasi miskonsepsi peserta didik juga mendapat porsi yang penting dalam menunjang pemahaman karena dalam penerapan model pembelajaran juga harus di dukung oleh cara-cara yang relevan untuk mengatasi permasalahan miskonsepsi dalam pembelajaran fisika [12].

Dari hasil penelitian yang dilakukan aktivitas dan hasil belajar siswa meningkat secara drastis dan signifikanhal ini sesuia dengan penelitian sebelumnya [6] yaitu pada siklus I sebesar $64,41 \%$ dan pada siklus II sebesar 90,0\% dan sesuia dengan penelitian yang dilakukan pada peneliti ini sesuai dengan apa yang didapat yaitu sama-sama meningkat.

Penelitian yang dilakukan sesuai dengan hipotesis yang diajukan yaitu penerapan model pembelajaran kooperatif tipe investigasi kelompok dapat meningkatkan aktivitas dan hasil belajar siswa fisika kelas X MA Raudlatusshibyan NW Belencong dan penerapan model pembelajaran kooperatif tipe investigasi kelompok dapat mempengaruhi aktivitas dan hasil belajar siswa fisika kelas X MA Raudlatusshibyan NW Belencong

\section{SIMPULAN DAN SARAN}

Berdasrkan hasil penelitian penelitian dan pembahasan, dapat disimpulkan bahwa aktivitas dan hasil belajar siswa dapat ditingkatkan melalui penerapan model pembelajaran kooperatif tipe investigasi kelompok. Peningkatan aktivitas dan hasil belajar siswa dapat dilihat dari hasil penelitian yang telah dilakukan. Untuk aktivitas 
belajar siswa pada siklus I diperoleh skor 60\% dan untuk siklus II diperoleh skor $85 \%$. Sedangkan untuk hasil belajar siswa menggunakan tes soal pilihan ganda dan essay diperoleh skor 71,87\% dan untuk siklus II diperoleh skor 87,5\%.

Berdasarkan kesimpulan maka beberapa saran yang diusulkan sebagai upaya perbaikan adalah: Pertama, Model pembelajaran kooperatif tipe investigasi kelompok dapat digunakan dan dikembangkan sebagai upaya meningkatkan kualitas pembelajaran, karna berdasrkan penelitian yang dilakukan, siswa dapat meningkatkan aktivitas dan hasil belajar, bekerjasama serta mandiri dalam belajar. Kedua, Bagi peserta didik, guru, dan semua pihak sekolah MA Raudlatusshibyan NW Belencong agar terus berusaha mengembangkan dan mencari inovasi maupun kreativitas pembelajaran Fisika terutama yang berhubungan dengan model pembelajaran kooperatif tipe investigasi kelompok. Ketiga, Bagi peneliti lain yang berkeinginan untuk melakukan penelitian sejenis sebaiknya tidak hanya membatasi peserta didik dalam upaya peningkatan kemampuan peserta didik dalam menyelesaikan permasalahan, tetapi juga variabel yang ditingkatkan dan bidang lain.

\section{DAFTAR PUSTAKA}

[1] Puri Nur'aini Agustin, dkk. (2017). Pembelajaran Fisika Di Sma Dengan Menggunakan Model Kooperatif Tipe Stad (Kajian: Di SMAN 1 Tapen Bondowoso). Jurnal Pembelajaran Fisika, 6 (2), 201-207.

[2] Ningtyas, Esthi Santi, dkk. (2017). Penerapan Model Pembelajaran Kooperatif (Cooperative Learning) Tipe Make-A Matchberbantuan Media Komik Interaktif Untuk Meningkatkan Aktivitas Belajar Dan Hasil Belajar IPS. Jurnal Pendidikan Surya Edukasi (IPSE), 3 (1), 67

[3] Didik, Lalu A., Wahyudi, M., Kafrawi, M. (2020). Identifikasi Miskonsepsi dan Tingkat Pemahaman Mahasiswa Tadris Fisika pada Materi Listrik Dinamis Menggunakan 3-Tier Diagnostic Test. Journal of Natural Science and Integration, 3(2), 128-137.

[4] Nur Akly dan Andi Halimah (2015). Efektivitas Penerapan Model Pembelajaran Kooperatif Tipe Group Investigation (Gi) Terhadap Hasil Belajar Fisika. Jurnal Pendidikan Fisika. 3 (1), 52-57.

[5] Masjudin. (2016). Pembelajaran Kooperatif Investigatif Untuk Meningkatkan Pemahaman Siswa Materi Barisan Dan Deret. JEMS (Jurnal Edukasi Matematika dan Sains), 4 (2), 76-84

[6] Yusniati H dan Muh. Yusuf. (2016). Penerapan Model Pembelajaran Kooperatif Tipe Group Investigation untuk Meningkatkan Hasil Belajar Fisika Hukum Newton tentang Gravitasi pada Siswa Kelas XI IPA1 SMA Negeri 7 Kupang. Jurnal Sains dan Pendidikan Fisika, 12 (1). 1-13.

[7] Yupin Aliwu, dkk. (2016). Penerapan Model Pembelajaran Kooperatif Tipe Group Investigasi Untuk Meningkatkan Aktivitas dan Hasil Belajar Siswa Kelas VI SDN No. 1 Labuan Bajo. Jurnal Mitra Sains, 4 (2), 46-53. 
[8] Wahyudi, M. dkk. (2017). A Learning Design: Integrating Tracker in Level of Inquiry to Enhance Seven Grade Student Science Process Skills and Graph Interpretation. $4^{\text {th }}$ ICRIEMS Proceedings. 65-70.

[9] Muji, R., Wahyudi, M., dan Zohdi M. (2020). Pengembangan Alat Peraga Gaya Elektromagnetik sebagai solusi Media pembelajaran Fisika di MA Al-Maarif Qomarul Huda Montong Are. KONSTAN, 5 (1), 18-26.

[10] Sudjana, N. (2011). Penilaian Hasil Proses Belajar Mengajar. Remaja Rosdakarya: Bandung.

[11] Didik, Lalu A. (2019). Workshop Pembuatan Media Pembelajaran Listrik Magnet dari Barang Bekas untuk Meningkatkan Kompetensi Mahasiswa Calon Guru Fisika. Jurnal Pengabdian Masyarakat MIPA dan Pendidikan MIPA, 3 (2). Hal. 70-74

[12] Didik, Lalu A dan Fitratul Aulia. 2019. Analisa Tingkat Pemahaman dan Miskonsepsi pada Materi Listrik Statis Mahasiswa Tadris Fisika Menggunakan Metode 3-Tier Multiple Choices Diagnostic. Phenomenon, 9 (1), hal. 99-111 